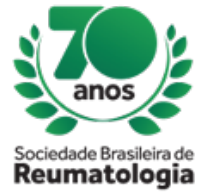

\title{
WORKING STATUS AMONG PATIENTS WITH RHEUMATIC DISEASES IN BRAZIL
}

Álvaro Luiz Teixeira de Freitas (Universidade Positivo, Curitiba, PR, Brasil), Ana Clara Aguiar Dávila (Universidade Positivo, Curitiba, PR, Brasil), Maryane Pletz Cortes Chaves (Universidade Positivo, Curitiba, PR, Brasil), Niels Vinícius Pádua Carvalho (Universidade Positivo, Curitiba, PR, Brasil), Thaís Farah Lundgren (Universidade Positivo, Curitiba, PR, Brasil), Cátia Figueiredo (RecomeçARR, Rio de Janeiro, PR, Brasil), Ana Geórgia Simão (A Menina e o Lúpus, Fortaleza, PR, Brasil), Alessandra de Souza

(Farmale, Rio de Janeiro, PR, Brasil), Ana Lúcia Paduello (Grupar-RP, Ribeirão Preto, PR, Brasil), Eni Maria da Silva (Associação Brasileira Superando o Lúpus, São Paulo, PR, Brasil), Marta Azevedo (Garce, Fortaleza, PR, Brasil), Carlos Eduardo Tenorio (Grupasp, São Paulo, PR, Brasil), Samuel de Oliveira (Espondilite Brasil, São Paulo, PR, Brasil), Priscila Torres da Silva (EncontrAR, São Paulo, PR, Brasil), Christopher Douglas Kache (Adore, Curitiba, PR, Brasil), Samira Tatiyama Miyamoto (Grupaes, Vitória, PR, Brasil), Bruna Burko Rocha Chu (Universidade Positivo, Curitiba, PR, Brasil), Kátia Sheylla Malta Purim (Universidade Positivo, Curitiba, PR, Brasil)

\section{BACKGROUND}

Patients with rheumatic diseases often suffer from intense pain, morning stiffness, and eventual loss of mobility and joint deformity. Therefore, there's a significant impact on patients' productivity, which implies in negative consequences to their employability. This is relevant to the patient, their families and society itself. The purpose of this study is to describe rheumatic patients working status, and whether they're benefitting from the disabled laws or social security.

\section{MATERIALS AND METHODS}

An anonymous web-based questionnaire through Google Forms was publicly available for 4 months in 2018. Social media and rheumatic disease blogs were used to promote the survey. Patients self-reported demographic data, information regarding their disease and treatment, as well as their work situation, and if their mobility was decreased. Data collected were exported to Microsoft Excel and statistical analysis was performed using IBM-SPSS.

\section{RESULTS}

2030 people answered the online survey claiming to be rheumatic patients. Table 1 shows their current job situation. Most of the patients claimed to be working on regular jobs. $9.6 \%$ benefit from social security disability and only $1.72 \%$ work through disabled laws. $61 \%$ claimed to have decreased mobility.

\section{CONCLUSION}

Intervention in the course of rheumatic diseases helps to minimize sequelae and to reduce disability rates. However, when this is not achieved, rheumatologic patients live with limitations that often demand rehabilitation or even withdrawal from the job market. This initial observation suggests that unemployment rate for this population is high and that few patients are benefiting from work-disabled laws. 